\title{
Interpretation on the Dill-pickle of Love
}

\author{
Xianxian Wang \\ Department of Foreign Studies, Dezhou University, Dezhou, China \\ Email: tomzoe_cn@sina.com
}

\begin{abstract}
On the analysis of major writing devices of "A Dill Pickle" as symbolism, stream of consciousness and further contrasting heroine and the hero of A Dill Pickle, the paper aims to find out the essence of love that true love maintains its passion and dynamism through mutual trust and the art of communication in case that love should fade away over years like the tasteless pickles.
\end{abstract}

Index Terms - symbolism, stream of consciousness, contrast, character, love

\section{INTRODUCTION}

Katherine Mansfield (1888-1923), a famous female short story writer, is often compared to Chekov, the great storyteller. Critics praised her for her capturing the essence of Chekhov's art for stories emphasizing atmosphere and actual life rather than exciting plot, and for her "refreshing originality" and "sensitiveness to beauty". A Dill Pickle, completed in 1917, is one of her the most significant masterpieces and it is based on her own experience. She ended her early marriage in 1909 and encountered Francis Hayman in 1910 and fell in love with him. They shared the plan to travel in Russia and arranged their marriage while his family opposed to their marriage for Katherine Mansfield's divorce. Francis Hayman was forced to end their relation. It was not long before Mansfield was pregnant and writing to Hayman in hope that he would come to see her, however in vain. Alone and lonely, she went to Germany and the child was aborted. Then six years later, they met with each other in a restaurant. A Dill Pickle reveals the loneliness and disillusionment of the female in reality as well as the author's passive, doubtful attitude towards love, as Mansfield put that there would be no happy ending for the man and the woman, since the woman was always the victim of the man, who was cool and arrogant.

A Dill Pickle is about the encounter between a young woman and a young man who have been lovers six years ago and their lost love and changes over the years. Vera, the heroine, not much of a speaker is very sensitive inside while the Man, the hero, good at the flowery words seems so insensitive and self-centered. Their different characters vividly reveal in the text in spite of almost the equal importance the author attached. Through the disharmony between their ways of communication, it could be inferred the divergence of their love and the shortcomings in their personality traits. Short as the text is, it shows the striking features of modernism between the lines: the trivialized plot, stream of consciousness, symbolism which make the text delicate and thought-provoking.

Integrated with the theme, writing devices of the text and contrasting between the heroine and the hero, it makes sense to further apprehend and appreciate the text.

\section{THE THEME AND WRITING DEVICES OF THE TEXT}

Katherine Mansfield reiterated her consistent theme in A Dill Pickle that the incomprehensible loneliness and pursuit of independence of personality of the female. Vera is the image of herself that they are both weak, fragile and love music, travelling, and have a deep complex to Russia. Through Vera's eyes, Katherine depicts the mysteriously exotic Russian scenery and presents her confusion and doubts to love.

With the unfolding of the conversation between Vera and the man, the writing devices as symbolism and stream of consciousness, their destiny and characters of the heroine and the hero appear more vivid and striking.

The story is set in a café, in which each prop, a scene serves the theme of the story yet appearing irrelevant. Vera's decent dressing suggests her weak health and middle class social status; the Japanese vase, the bamboo table, and cigarette case shows the Man's unusual taste; the warm afternoon on which various flowers came into blossom tells the happiness of Vera; while the darkening Vodka river, mysterious Black Sea, and the melancholy tress indicates the worsening sentiments of Vera. The Dill Pickle, the preserved vegetable as a piece of snack, comes up twice in the text first in the Man's recollection and then in Vera's imagination. Although Vera doesn't see the pickles in person, she is so sensitive that she can feel the bright color and the sour taste of the pickles all out of her intuition. The dill pickle symbolizes the loss of the dynamism of their once fiery love as much as the lost flavor of fresh vegetables, besides it further tells that as for the man, love between a man and a woman is like nothing but the ingredient of his colorful life once tasted, and tasteless afterward. Hence, symbolism helps to invent the vivid figures of the text and makes the theme of the text more profound.

Katherine Mansfield doesn't make Vera's speak much in the text, on the contrary, she goes deep into Vera's inner world. Through Vera's recollection, association and imagination-the flowing of consciousness, the whole story over the 
six years unfolds. With the writing device as the stream of consciousness, Katherine Mansfield lets Vera tell and introduce her relationship with the Man. The Man keeps speaking and Vera listening to him, searching memory over the six years, piecing together their relations and presenting their story to the readers. Say, his interrupting her speaking reminds her of his irritating trick of interruption six years ago; his talking of those flowers leads her to remember the absurd scene over the tea table, his waving away the wasps like a maniac, out of all proportion to the occasion; his speaking of traveling around the places they have planned together, especially that informal, free Russian life wakes up the strange beast which has long slumbered in her bosom- her long cherished wish for the carefree and impulsive life.

With the stream of consciousness, characters of the heroine and the hero are more than alive.

\section{Different Attitudes to Love through Contrasting Vera AND the MAN}

Katherine Mansfield was good at inventing female characters as well as the male characters. Besides, the images of the male display the Katherine's observations on the problems between men and women brought forth by their respective social status and family background, and their intricate relations in that male chauvinist society. From her unique female perspective and extraordinary writing techniques, she reflected on the living situations of the female, revealed and sharply criticized the society of male chauvinism, which was ahead of her time and far from precious.

\section{A. Contrast on their Styles of Communication}

The disharmony between their styles of communication exposes the drastic differences in their characters. Six years ago they were lovers, interruption her speaking was his annoying trick in Vera's eyes; six years later, he is with habit of interruption. He is so excited to be listened to. Indeed, he is too much of a good speaker. The conversation between them through the whole text is almost voiced by the Man about his experience, his feelings, his decent life, which serve his own purpose that he enjoys his success and mocks and trivializes the deterioration of Vera's situation.

Vera has to be listening upon their encountering. Delicate, melancholy as she is, she is sensitive to each of his words. Her love to him has been intricate and complex, as bitter and sour as the preserved pickles. She has been doubtful about whether it was wise to leave him. She is hesitant as his sweet words pour out till eventually she realizes he is still he used to be and she leaves him again with him "sitting there, thunder-struck, astounded beyond words".

\section{B. Contrast on the Social Status between Vera and the Man}

The abovementioned differences between their way of communication comes from their family background and social status which further result in their separation six years later.

From the very beginning of the text, Vera "raised her veil and unbuttoned her high fur collar", the decent dressing indicates Vera's special taste to her appearance; as the story develops, it tells that Vera once enjoyed a pleasant life and her decent family background; she has the great interest in flowers, perfumes, music and travelling, which further suggests her special sensitivity to beauty. On the contrary, the Man, six years ago, young and naïve, had the dreamy vagueness and indecision what he behaved on that particular afternoon out of proportion to the occasion was like the nightmare for Vera.

Then in the following six years, they both have experienced drastic changes that Vera faces the declining of her middle-class family, down and out, struggles to live a life in the harsh reality while the man has been enjoying a decent life-he has the air of a man who has found his place in life and he must have made money too. But he remains the same as before in that he still has the trick of interrupting Vera, boasting all about his success and indulging in his dreams in negligence of Vera's sentiments.

For all the reasons, it can be inferred in the text the drastic difference of their social status and values result in their separation. Their social status seems equal but the rooted differences written in their genes remains as much as six year ago.

\section{Contrast on the Differences between their Personality Traits}

In the story, the author artfully points out the Man's insensitivity to others and Vera's sensitivity. The initial glimpse of the Man's self-involvement comes in that: he doesn't recognize her at first, then after a few words, he resorts to his old habit of interrupting her; then his egoism blinds him from seeing and caring Vera's deterioration and feelings and he has been imbued with the fantasy of what he has done in the six years, by himself, all the things they have dreamed of doing together-in particular, travelling to Russia, the best-cherished place in Vera's heart. At the end, he has the audacity to claim that they are both egotistical and self-engrossed which sharply proves his egoism.

Throughout the text, Vera doesn't do much taking, and it is plain to feel her sensitiveness between the lines: she is not only sharply aware of his feelings, in fact more so than he himself is, and feels more strongly his pains and joys. She was also courageous to end the relationship with him because he was too egoistical. Six years later, she leaves him again since she recognizes that he has not changed.

Contrasting the differences of the personality traits of Vera and the Man, Katherine Mansfield tried to reflect and explore the art of communication between the female and the male. And it could be better noticed the limit that Katherine Mansfield focused her attention mainly on the lost love between the two persons without offering effective solutions to amend their relations in the confusing and complicated reality. 


\section{CONCLUSIONS}

The ending of the story indicates the failure of love that for all of their regrets over the love in the past six years, and in the end love still fades away like the preserved pickles which have long lost their taste and flavor. It should further be stressed that the fatal weaknesses in their personalities- egoism and lack of art of communication result in the failure of love.

That Vera's leaving in the end represents Katherine's attitude to love and disappointment with the male and disillusionment of the female in the society, which makes the readers think over the flavor of true love, or the love as tasteless as the preserved dill pickles is not worth cherishing.

\section{REFERENCES}

[1] Yahui He. (1999). On the Modernism of Katherine Mansfield. Journal of Shanghai University, 2, 41-45.

[2] Antony Alpers. (1982).The Stories of Katherine Mansfield. Oxford: Oxford University Press.

[3] Hong Jiang. (2004). Contradicting Identity of the Characters in Katherine Mansfield Works. Beijing: China Social Science Press.

[4] Liangting Chan. (1983). The Novels of Katherine Mansfield. Shanghai: Shanghai Foreign Language Press.

[5] Limin Yang. (ed) (2002). A Dill Pickle. Contemporary College English. Beijing: Foreign Language Teaching and Research Press.

Xianxian Wang was born in Dezhou, China in 1980. She studies at the School of Foreign Studies in Shandong University of Finance between 1999 and 2003. She received her Bachelor's degree in 2003. She has furthered her study on English education for Master's degree in Shandong Normal University since 2008. Her major field of study is English education.

She has worked in the Department of Foreign Studies in Dezhou University since 2003. Her professional title is lecturer. Her major theses include: The strategy to enhance the motivation of English major for learning Japanese as the second foreign language (Beijing, China: China Electrical Engineering Education, 2010); The elements that affect Chinese students' English pronunciation and intonation (Dezhou, China: Dezhou University Journal, 2008).

Miss Wang won the Best English Public Speaker Award for the Shandong Provincial Teachers' Talents Competition in 2008. She was the first prize winner for Teaching Competition in Dezhou University in 2009. She was honored one of the "Most Promising Young Teachers" of Dezhou University in 2010. 